ISSN No. 0974-035X

An indexed refereed \& peer-reviewed journal of higher education

Towards Excellence

UGC-HUMAN RESOURCE DEVELOPMENT CENTRE

Gujarat University, Ahmedabad-380009, Gujarat, India

\title{
BIREMEDIATION OF PESTICIDES - A REVIEW
}

\author{
Priyanka Gajjar \\ Nidhi Gondaliya \\ Ankita Patel \\ Hiral Shah
}

\begin{abstract}
Green revolution is one of the basic need to save our planet and our country from burning environmental issues, there were quantum bounce in the use of synthetic pesticides which play an important role in agriculture to control destructive pests such as insects, weeds, plant disease causing pathogenic organisms, nematodes, arthropods and vertebrates, that cause danger to quality of food products such as fruits and vegetables, hazardous to the environment, affects soil fertility and causing imbalance in nature. Currently there have been some Physico -chemical and biological methods which are used to reduce pesticides. However, these methods are not efficient, cost effective and time consuming. Whereas, bioremediation is novel tool or ecofriendly approach used for cleaning up contaminated environments using different microbial species such as bacteria, fungi, Actinomycetes and some green plants. Bioremediation is less invasive method, ecofriendly, economical, more efficient and restorative of soil function. Most of the pesticides generally fall into the major classes of organochlorines, chlorophynoxy acids, carbamates, organophosphorous. My present study focused on understanding bioremediation mechanisms, involvements of different microbes and its vital role in removing pesticides of different categories.
\end{abstract}

Key words: Bioremediation, biodegradation, xenobiotics, anthropogenic activity, pesticides, organochlorines, chlorophynoxy acids, carbamates, organophosphorus.

\section{Introduction}

\section{Degradation of soil quality}

In cutting-edge agricultural system, chemical fertilizers and pesticides play an essential role in increasing crop yields and productivity. Soil play crucial role as plant growth promoting 
Towards Excellence: An Indexed, Refereed \& Peer Reviewed Journal of Higher Education / Ms. Priyanka Gajiar, Ms. Nidhi Gondaliya, Ms. Ankita Patel \& Ms. Hiral Shah/ Page 507-526

medium and have many other functions such as exchange of gases such as carbon dioxide, carbon monoxide, nitrogen dioxide and sulfur dioxide (Rani, Kavita, and Geeta Dhania, 2014), flow of energy, nutrients and water, detoxification of pollutants make balance of ecosystem, also it contains organic matter as well as inorganic mineralPrashar, Pratibha, and Shachi Shah, 2016).

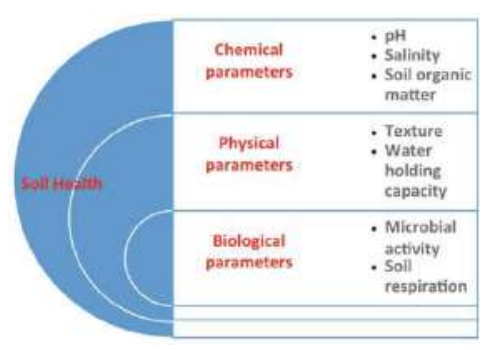

Fig: Physical, chemical and biological parameter adepted from Prashar, Pratibha, and Shachi Shah, 2016.

The unexpectedly urbanization, industrialization, growing population and over usage of pesticides has been acknowledged to the surroundings, have release xenobiotic compounds and decrease soil fertility (Parte, Satish G et al., 2017).Soil may be degraded and the network of organisms residing inside the soil may be broken via the misuse or over use of pesticides. Some pesticides are more toxic than natural microbes and readily degraded in the soil while some of the pesticides remain in the soil and cause damage of soil (http://npic.orst.edu/). In other words soil degradation is a system, which lowers the density potential of the soil to produce items and unfavorable modification in nutrient fame, soil organic count, structural attributes, and concentration of electrolyte and toxic chemical compounds adversely affected the physical, chemical and biological properties of soil Feng, Shuyue, et al., 2019 and Aulakh, Milkha S., and Gurjant S. Sidhu2015).

\section{Pesticides}

Pesticides are group of chemical substances or mixture of substances intended for preventing, destroying, repelling, or mitigating any pest including insecticides, herbicides, fungicides and various other substances used to control pest (Zhanget al., 2011). Pesticides have made great impact on human health and preservation of food fibre. Plants more than $55 \%$ of the land used for agricultural production in developing countries use about $26 \%$ of the total pesticides produced in the world (Radhika, M., and M. Kannahi., 2014). Excellent benefits have been derived from the uses of pesticides in forestry, public fitness, in agriculture and in the domestic shear. In the 1948-49 the agricultural production was 50 million tons, it had been 
Towards Excellence: An Indexed, Refereed \& Peer Reviewed Journal of Higher Education / Ms. Priyanka Gajiar, Ms. Nidhi Gondaliya, Ms. Ankita Patel \& Ms. Hiral Shah/ Page 507-526

increased fourfold 198 million tons by the end of 1996-97 by the use of pesticides (Aktar, W et al., 2019).Behind China, India is ranked handiest $2^{\text {nd }}$ in Asia and $12^{\text {th }}$ in the international in pesticide production and hardly $2-3 \%$ pesticide residues are virtually utilized and the rest of pesticides remain in soil and water causing harmful effect in biota and accumulated in human body mainly in blood, adipose tissue and lymphoid organs also cause mutation in chromosomes of men and animal and lead to carcinoma in lung and liver via food consumption. They are teratogenic and mutagenic have ability to cause hepatotoxicity, neuropathy, nephropathy, and reproductive disorders (AHMAD, MASOOD, and IRSHAD AHMAD2014).

\section{Classification of pesticides}

Pesticides encompasses a variety of different types of chemicals including herbicides, insecticides, fungicides and rodenticides. They are classified on the bases of structure including organochlorine, organophosphorus, carbamates, nitrogen-based pesticides (Uqab. et al., 2016).Pesticides classified by three method such as classification based on pesticides function and target organisms, mode of entry, and based on chemical composition. (Yadav, et al., 2017).

Table: 1 Classification Based on their target pest (Yadav, et al., 2017and Mieldazys, A et al., 2015)

\begin{tabular}{|c|c|c|}
\hline $\begin{array}{l}\text { Group of } \\
\text { Pesticides }\end{array}$ & Target Organisms & Example \\
\hline Acaricides & $\begin{array}{l}\text { Kill mites, ticks that feed on plants } \\
\text { and animals }\end{array}$ & $\begin{array}{l}\text { DDT, dicofol, carbofuran, methiocarb, } \\
\text { propoxur, abamectin, milbemectin, } \\
\text { flufenoxuron, chlorpyrifos, oxydemeton } \\
\text { methyl, phorate, phosalone, } \\
\text { fenpyroximate, fipronil, cyhalothrin, } \\
\text { fluvalinate, permethrin, Bifenazate }\end{array}$ \\
\hline Algaecide & Kill or inhibit growth of algae & $\begin{array}{l}\text { Diuron, isoproturon, oxyfluorfen, } \\
\text { simazine. }\end{array}$ \\
\hline Antifeedant & $\begin{array}{l}\text { Prevent an insect or other pest } \\
\text { from feeding }\end{array}$ & chlordimeforn, fentin and azadirachtin \\
\hline Avicides & Kill birds & Fenthion, strychnine, Avitrol \\
\hline Bactericides & $\begin{array}{l}\text { Kill or inhibit bacteria in plant or } \\
\text { soil }\end{array}$ & $\begin{array}{l}\text { Copper hydroxide, kasugamycin, } \\
\text { streptomycin, tetracycline, copper }\end{array}$ \\
\hline
\end{tabular}


Towards Excellence: An Indexed, Refereed \& Peer Reviewed Journal of Higher Education /

Ms. Priyanka Gajjar, Ms. Nidhi Gondaliya, Ms. Ankita Patel \& Ms. Hiral Shah/ Page 507-526

\begin{tabular}{|c|c|c|c|}
\hline & & compexes & \\
\hline Bird repellents & Act as bird repellents & $\begin{array}{l}\text { Copper oxychloride, } \\
\text { methiocarb, thiram, ziram. }\end{array}$ & diazinon, \\
\hline Insecticides & Kill insects and other arthropods & Aldicarb & \\
\hline Fungicides & Kill fungi & Azoxystrobin & \\
\hline Herbicides & $\begin{array}{l}\text { Kill weeds and other plants that } \\
\text { grow where they are not wanted }\end{array}$ & Atrazine, metribuzin & \\
\hline Rodenticides & Control mice and other rodents & Warfarin & \\
\hline Larvicides & Inhibits growth of larvae & Methoprene & \\
\hline Nematicides & $\begin{array}{l}\text { Kill nematodes that acts as } \\
\text { parasite of plant }\end{array}$ & Aldicarb & \\
\hline
\end{tabular}

Table: 2 Classification based on Chemical structure (Garcia, et al., 2012, Uqab, et al., 2016, Sharma, A. N. I. T. A., et al., 2016)

\begin{tabular}{|c|c|c|}
\hline Name & $\begin{array}{l}\text { Characteristics and } \\
\text { Chemical structure }\end{array}$ & Example \\
\hline Organophosphates & $\begin{array}{l}\text { Broad spectrum pesticides, } \\
\text { Esters of phosphoric acid, } \\
\text { more stable and less toxic } \\
\text { than organochlorine, can be } \\
\text { aromatic, cyclic or } \\
\text { heterocyclic }\end{array}$ & $\begin{array}{l}\text { Diazinon, dichlrovos, dimethoate, } \\
\text { malathion, parathion. }\end{array}$ \\
\hline Organochlorine & $\begin{array}{l}\text { Containing carbon atom } \\
\text { may be chlorine, hydrogen } \\
\text { and oxygen, non-polar and } \\
\text { lipophilic in nature, tend to } \\
\text { accumulate in fatty tissue }\end{array}$ & $\begin{array}{l}\text { DDT, methoxyclor, toxaphene, } \\
\text { mirex, kepone }\end{array}$ \\
\hline Carbamate & $\begin{array}{l}\text { Esters derived from acid or } \\
\text { dimethyl N-methyl } \\
\text { carbamic acid, less } \\
\text { persistent then } \\
\text { organochlorine and } \\
\text { organophosphates, inhibit }\end{array}$ & $\begin{array}{l}\text { Carbaryl, propoxure, aldicarb } \\
\text { methiocarb, carbofuran, aminocarb, } \\
\text { seven, mecozeb, carbendazim }\end{array}$ \\
\hline
\end{tabular}


Towards Excellence: An Indexed, Refereed \& Peer Reviewed Journal of Higher Education /

Ms. Priyanka Gajjar, Ms. Nidhi Gondaliya, Ms. Ankita Patel \& Ms. Hiral Shah/ Page 507-526

acetyl cholinesterase, kill

limited spectrum of insects,

Pyrethroids Organic pesticides, Cypermethrin, permethrin,

synthesized from pyrethrin,

affect the nervous system,

Table: 3 Classification based on their mode of entry (Yadav, et al., 2017, Akashe, Megha

Met al., 2018)

\begin{tabular}{|c|c|c|}
\hline Name of pesticides & Mode of entry & Example \\
\hline Systemic pesticides & $\begin{array}{l}\text {-Absorbed throughplants } \\
\text { and animal tissues and } \\
\text { reached to untreated areas of } \\
\text { roots, leaves, stems. } \\
\text { - Penetrate in plant tissue } \\
\text { and flow through plant } \\
\text { vascular system to kill } \\
\text { definite pest }\end{array}$ & $\begin{array}{l}\text { 2,4-Dichlorophenoxyacetic } \\
\text { acid (2,4-D), Glyphosate }\end{array}$ \\
\hline $\begin{array}{l}\text { Non-systemic/contact } \\
\text { pesticides }\end{array}$ & $\begin{array}{l}\text { - it acts on course pests } \\
\text { when they arrive in touch. } \\
\text { - enters into body via } \\
\text { epidermis upon contact and } \\
\text { cause death through contact }\end{array}$ & Paraquat, diaquat dibromide, \\
\hline $\begin{array}{l}\text { Stomach poisoning and } \\
\text { stomach toxicant }\end{array}$ & $\begin{array}{l}\text { - it enters the into the body } \\
\text { via their mouth and } \\
\text { digestive system and cause } \\
\text { death by poisoning } \\
\text { - stomach toxicants also } \\
\text { cause death by entering to } \\
\text { mouth and digestive system } \\
\text { of pest's body }\end{array}$ & Malathion \\
\hline Repellents & $\begin{array}{l}\text { - they do not kill but } \\
\text { distasteful to keep away } \\
\text { from treated areas }\end{array}$ & Methiocarb \\
\hline
\end{tabular}


- they interfere with pest's

ability to locate crop

Fumigants

- they kill the pest by Phosphine

producing vapor or

poisonous gas which enters

respiratory system of pest's

and cause death

There are two types of natural insecticides includingAzadirachta indica, Boenighauseniaalbiflora, Peganum harmala, Derris and Chrysanthemum and synthetic insecticides including organochlorines, organophosphates, carbamates and pyrethroids, Ethylene dibromide (EDB) is a volatile liquid (fumigant) used in controlling insect pests in stored grains and fruits.

\section{General properties of pesticides}

\section{Molecular weight:}

The molecular weight, appearance and odor of the active ingredients are the physical characterization of pesticides in which atomic weight of individual atom is referred to as molecular weight, it is an inherent property that differentiate one form of pesticide to another form of pesticide. Stereoisomeric group of pesticides have a similar molecular weight but their spatial orientation is differing from each other such as chiral group is difficult to distinguish from each other (Zacharia, James Tano., 2011).

\section{Vapor pressure:}

Vapor pressure is another property of pesticide which is interrelated with volatility and it is dependent on the size and functional groups of an organic compound. Vapor pressure is used to measure the tendency of product which transfer from liquid or solid phase to gas form. Vapor pressure also used to determine the volatilization, which is greatly alter by temperature and is depend on the solubility, wind, chemical properties and soil (Pereira, Vanderley José, et al., 2016).

\section{Solubility:}

Maximum amount of molecule dissolved in water is known as solubility which is measured in $\mathrm{mg} / \mathrm{l}$ or parts per million. Solubility of water is influenced by such parameter like $\mathrm{pH}$, 
Towards Excellence: An Indexed, Refereed \& Peer Reviewed Journal of Higher Education / Ms. Priyanka Gajiar, Ms. Nidhi Gondaliya, Ms. Ankita Patel \& Ms. Hiral Shah/ Page 507-526

Temperature, polarity of the substance, hydrogen bonding, molecular size and the method used (Zacharia, J. T. 2011). Chemicals with higher water solubility have low adsorption coefficient and bio-concentration factors, reach to greater depths and tend to biodegrade rapidly in soil and water (Pereira, Vanderley José, et al., 2016).

\section{Water partition coefficient (Kow):}

Partition coefficient is referred to as the ratio dissolve chemical concentration of octanol is divided by its concentration in water higher values suggested that a pesticide is very strongly connected to soil.

$$
\text { Kow }=\frac{\text { Concentration in n-octanol Phase }}{\text { Concentration in water phase }}
$$

The measurement of Kow is necessary to evaluate many chemical properties like solubility and bioconcentration factor and hence it is gives details about distribution of chemical in the environment (Pradhan, A. N. U. P. A. M. A, et al., 2014).

\section{Soil adsorption coefficient $K_{o c} / K_{d}$ :}

For the determination of the degradation process and destination of pesticides in environment, soil adsorption coefficient is very necessary factor. $K_{d}$ is the sorption coefficient which measures the amount of pesticides tend adsorbed onto soil per amount of water without considering the organic matter content of the soil and $\mathrm{K}_{\mathrm{oc}}$ is the ratio of the mass of substance adsorbed onto a unit of mass of soil, relative to the mass of the substance remaining in water solution. $\mathrm{K}_{\mathrm{oc}}$ depends on polarity, salinity, $\mathrm{pH}$ and organic content (Zacharia, James Tano., 2011).

\section{Hydrolysis reaction of pesticides:}

When pesticides reacted with water molecules it is hydrolysed and gives new product. The half-life value of hydrolysis is used to determine the persevere chemical residues in the environment and it is depending on the $\mathrm{pH}$ and temperature (Pradhan, A. N. U. P. A. M. A, et al., 2014).

\section{Photodegradation and microbial reduction:}

The process of photodegradation or photolysis is caused by the sunlight absorption usually ultraviolet rays used which can break down the molecular bonds present between the substance. Those pesticides which are not degraded by photolysis or microbial reduction, they are persistent into soil and water and contaminate it. The substance of photodegradation can be measured by half-life (Pereira, V. J. et al., 2016). Microbial reduction of pesticide is occurred by the help of microorganism available in soil (Pradhan, A. N. U. P. A. M. A, et al., 2014). 
Towards Excellence: An Indexed, Refereed \& Peer Reviewed Journal of Higher Education / Ms. Priyanka Gajiar, Ms. Nidhi Gondaliya, Ms. Ankita Patel \& Ms. Hiral Shah/ Page 507-526

\section{Principle and mechanism of bioremediation}

"Biological response to environmental abuse" is referred as Bioremediation which is combination of two words: bio means biological and remediation which means to remediate or to eliminate, recently emerging method employed for clean-up strategies.Bioremediation is the process used to degrade the environmental contaminants or organic waste into much less toxic compound which are causing negative impact on human health as well as an ecosystem by using microbial flora like bacteria, algae, fungi, actinomycetes, yeast either indigenous organisms or used as a consortium under controlled condition to innocuous state. (Vidali, Mn. 2001). The main purpose of bioremediation is encouraging them to work by means of providing most appropriate level of nutrients and other chemical substances important for metabolism of microbes to detoxicate hazardous substance from the ecosystem and this all metabolism is carried out by some enzymes (oxidoreductase, hydrolase, lyases, transferases, isomerases and ligase ) which have non-specific and specific substrate affinity and have ability to attack on pollutants and convert them to less toxic substance (Endeshaw, A., et al., 2017).

\section{Types of Bioremediation Technology}

Bioremediation is one of the most promising eco-friendly, cost effective and important technology for the removal of xenobiotic compounds by microorganisms, green plants or their enzymes to return the natural environment altered by contaminants of original condition to preventing pollution, (Kulkarni, Amritha G., and B. B. Kaliwal., 2014).Traditional methods for remediation of contaminated soils are costly, and can include excavation, removal, and treatment of the contaminated soil and such methods are not economically viable for most agrochemical dealership (CFTRI, 2003).Bioremediation method is less invasive as well as more restorative of soil functions compared to conventional physicochemical methods. The recent advances in bioremediation technology using microbial consortium has been found effective for treatment of pesticides in soil. Bioremediation as sustainable technology has become important analysing the high release of anthropogenic chemicals into the environment (Geetha, M., andM. HFulekar., 2008). This method is categorized in two types such as In situ and ex situ method.

\section{In situ Bioremediation}

This biological treatment is used to clean up xenobiotic compounds from the water and soil which is not required complete remediation of soil. Microbes are used for the degradation of 
Towards Excellence: An Indexed, Refereed \& Peer Reviewed Journal of Higher Education / Ms. Priyanka Gajiar, Ms. Nidhi Gondaliya, Ms. Ankita Patel \& Ms. Hiral Shah/ Page 507-526

hazardous chemical substance hence it is more reliable, invasive and low-cost technology however there are some problems associated with this technique such as it is time consuming method, it is influenced by environmental factor, additives used in this method cause problems (Zaidi, et al., 2012).

\section{Ex situ Bioremediation}

Ex situ method is used to excavating pollutants from contaminated area and transfer to another area for remedy. This strategyis based on the value of remedy, depth of pollution, kind of pollutant, geographical location and geology of the polluted site and also performance criteria determine the preference of ex situ technique ((Zaidi, et al., 2012). Land farming, slurry phase biological treatment, composting, biopiles and bioreactors are the different methods including in ex situ remediation technology (Gavrilescu, Maria., 2005).

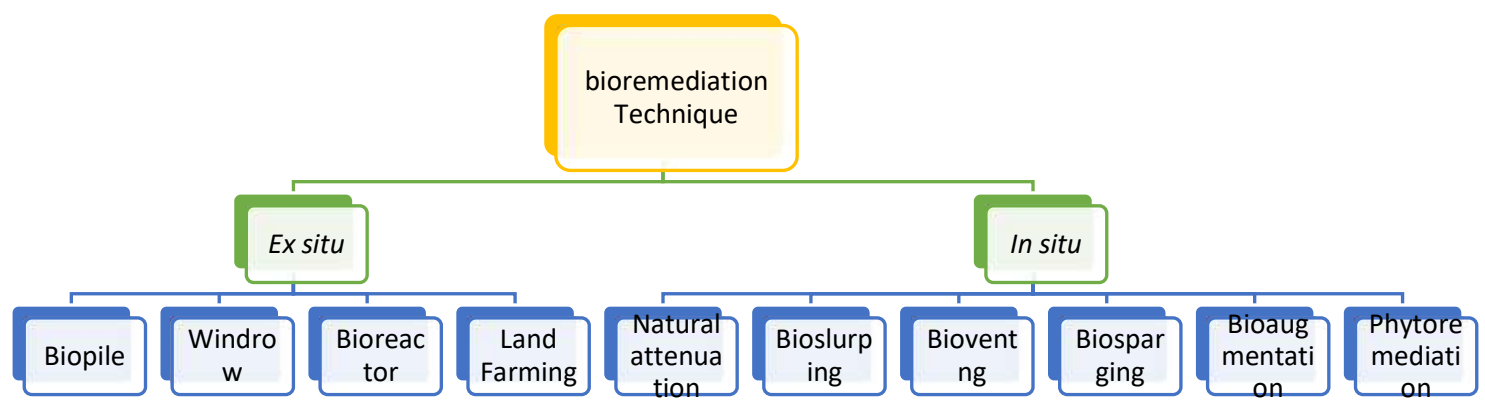

Fig: Different Methods of Bioremediation (Azubuike, et al., 2016).

\section{Role of bacteria in bioremediation}

Microbes are widely distributed on the biosphere and based on the ability to convert, modify and utilize toxic pollutants to clean up contaminated site (Endeshaw, A., et al., 2017). Many microbial species such as Pseudomonas spp. is well known biodegradable bacteria have ability to degrade agrochemical like cypermethrin is the pesticide which is degraded by bacterial species such as Pseudomonas aeruginosa, Klebsiella spp., Escherichia coli, Bacillus spp. and Corynebacterium (Kulkarni, Amritha G., and B. B. Kaliwal.., 2014). Carbamate group of pesticide such as carbofuran degradation is first time carried out by Sphingomonas spp. and Arthrobacter spp., carbarylremediateby Aeromonas, Pseudomonas, Bacillus andBorganella, propoxure, methomyl, carbendazim, are degraded by Corynebacterium kutscheri, S. aureus, B. pasteurii, E. coli, Stenotrohomonas spp., Sphingomonas spp., 
Towards Excellence: An Indexed, Refereed \& Peer Reviewed Journal of Higher Education / Ms. Priyanka Gajiar, Ms. Nidhi Gondaliya, Ms. Ankita Patel \& Ms. Hiral Shah/ Page 507-526

Rhodococcus spp., Nocardiodes respectively (Mustapha, Mohammed Umar, et al., 2019). Nicotinamide is the type of pesticide which is degraded by the Pseudomonas spp. (Uqab., et al., 2016). Lindane production is major in India and it is main source of Hexachlorocyclohexane which is carcinogenic pollutant that is banned all over word but is degraded by some species of Pseudomonas spp., Sphingobium spp., Mycobacterium spp., Pandoraea spp. and microbial consortia like PseudomonasflurescensbiovarII,Pseudomonas diminuta, Pseudomonas flurescensbiovarI, BurkholderiapseudomalleiLal, Rup, et al., 2008). Maximum pesticides produce some metabolites which are more toxic and less soluble in water which is partially degraded by nature and surrounding environments i.e Endosulfan is degraded by some fungi and bacteria produce poisonous endo sulphate and less toxic endosulfan, DDT is another example of pesticide which is produce two toxic metabolites by degradation like DDE and DDE (Rani, Kavita, and Geeta Dhania. (2014).

\section{Role of fungi in bioremediation}

Pesticide degradation is carried out with minor structural changes by fungi and release into soil by converting them into nontoxic substance, for example Flammulinavelupites, Stereumhirsutum, Coriolus versicolor, Dichomitussqualens, Hypholomafasciculare, Auricularia auricula are the some species of fungi which is degraded pesticides like triazine, phenylurea, dicarboximide, chlorinated organophosphorous compounds and white rot fungi is also able to degrade Heptachlor atrazine, terbuthylazine, lindane, metalaxyl, chlordane mirex, gamma hexachlorocyclohexane, dieldrin, diuron, aldrin, DDT (Uqab. et al., 2016 Singh, B. K., and R. C. Kuhad,1999). Mancozeb pesticide cause environmental risk because they have their own ecotoxicity, endocrine action, their potential to bioaccumulation and hence it is remediating by two fungal species such as Aspergillus niger and Aspergillus flavus(Aimeur, Nadjet, et al., 2016).

\section{Role of Actinomycetes in bioremediation}

Actinomycetes have ability to degrade high doses of pesticides and chemical complexes by producing chemical complexes and effective pesticides and are powerful and popular for their bioremediating property which is effectively transform xenobiotic compound into soluble or less harmless component by producing extracellular enzymes, the genera including Arthrobacter, Brevibacterium, Clavibacter, Corynebacterium, Mycobacterium, Nocardia, Nocardioides, Rhodococcus, Streptomyces etc(Salaria, Nehaet al., 2017 and Sette, Lara Det al., 2005). 
Towards Excellence: An Indexed, Refereed \& Peer Reviewed Journal of Higher Education / Ms. Priyanka Gajiar, Ms. Nidhi Gondaliya, Ms. Ankita Patel \& Ms. Hiral Shah/ Page 507-526

Table: 4 Study of Pesticide degradation by Actinomycetes.

\begin{tabular}{|c|c|c|}
\hline Genus of Actinomycetes & Types Pesticides & References \\
\hline Arthrobacter & $\begin{array}{l}\text { PCP, Phenoxyacetate } \\
\text { herbicides, Organochlorines, } \\
\text { triazine, } \\
\text { methylcarbamates, } \\
\text { organophosphates, } \\
\text { Glphosate, Atrazin }\end{array}$ & $\begin{array}{l}\text { Wang, H., et al., 2016, } \\
\text { Schrijver, Adinda De, and } \\
\text { René De Mot., } 1999 .\end{array}$ \\
\hline Bravibacterium, & Phenoxyacetate herbicide & $\begin{array}{l}\text { Schrijver, Adinda De, and } \\
\text { René De Mot., } 1999 .\end{array}$ \\
\hline Clavibacter & $\begin{array}{l}\text { Organochlorine and S- } \\
\text { trazines }\end{array}$ & $\begin{array}{l}\text { Schrijver, Adinda De, and } \\
\text { René De Mot., } 1999 .\end{array}$ \\
\hline Corynebacterium & Thiocarbamtes & $\begin{array}{l}\text { Schrijver, Adinda De, and } \\
\text { René De Mot., } 1999 .\end{array}$ \\
\hline Nocardia & Organoclorines & $\begin{array}{l}\text { Schrijver, Adinda De, and } \\
\text { René De Mot., } 1999 .\end{array}$ \\
\hline Streptomyces spp. & Diuron, Alachlor & $\begin{array}{l}\text { Esposito, et al., } 1998 \text { and } \\
\text { Sette, Lara. D et al., 2005). }\end{array}$ \\
\hline
\end{tabular}

\section{Role of enzymes in bioremediation}

Bioremediation of pesticides is generally based on microbes which are attack on toxic chemical components by enzyme production and convert them into risk free substance. Microbial growth like aerobic and anaerobic microbes are necessary for bioremediation which is influenced by environmental factor hence it is very slow process and these microbes are able to produce some intracellular and extracellular enzymes to remediate certain recalcitrant substances, lignin and organopollutants. Many xenobiotics and toxic components degraded by the many microbial enzyme by the oxidation reduction reaction occur by biochemical reactions in which chemical bonds of hazardous substance cleaved by transfer of electron from reduced organic substance to another organic compounds acts as acceptor (Karigar, Chandrakant S., and Shwetha S. Rao2011).

Table: 5 Studies on pesticides degrading enzymes with their source.




Towards Excellence: An Indexed, Refereed \& Peer Reviewed Journal of Higher Education / Ms. Priyanka Gajiar, Ms. Nidhi Gondaliya, Ms. Ankita Patel \& Ms. Hiral Shah/ Page 507-526

\begin{tabular}{|c|c|c|c|}
\hline $\begin{array}{l}\text { Oxidoreductase } \\
\text { (oxygenase, } \\
\text { Laccase, } \\
\text { Peroxidase) }\end{array}$ & \begin{tabular}{lcc} 
Alteromonasundina, & $B$. \\
diminuta, & Aspergillus & sp., \\
Penicillium & sp., & $R$. \\
practicola, & \multicolumn{2}{c}{ Tremetes } \\
versicolor & &
\end{tabular} & Organophosphate & $\begin{array}{l}\text { Parte, Satish Get } \\
\text { al., (2017),Sharma, } \\
\text { Babitaet al., } \\
(2018),\end{array}$ \\
\hline $\begin{array}{l}\text { Hydrolases (Lipase, } \\
\text { Cellulase, } \\
\text { Carboxylesterase, } \\
\text { Phosphodiesterase, } \\
\text { Dehalogenase, } \\
\text { Carbofuran } \\
\text { hydrolase) }\end{array}$ & $\begin{array}{l}\text { Klebsiella sp., Alcaligenes } \\
\text { sp., } \\
\text { Staphylococcus sp., } \\
\text { Pseudomonas sp., } \\
\text { Agrobacteriumrediobacter, } \\
\text { Serratia, Alteromonas, } \\
\text { Plesiomonas sp., } \\
\text { Pseudaminobacter, } \\
\text { Mesorhizobium, Ralstonia, } \\
\text { Ochrobactrum }\end{array}$ & $\begin{array}{l}\text { Organochlorine, } \\
\text { Carbamate, } \\
\text { Pyrethroid }\end{array}$ & $\begin{array}{l}\text { Sharma, Babitaet } \\
\text { al., (2018), Nagata, } \\
\text { Yuji, et al., (2015), } \\
\text { Parte, Satish G. et } \\
\text { al., (2017) }\end{array}$ \\
\hline Phytase & Aspergillus niger & Organophosphate & $\begin{array}{l}\text { Sharma, Babitaet } \\
\text { al., (2018). }\end{array}$ \\
\hline $\begin{array}{l}\text { Triazine } \\
\text { dechlorinase }\end{array}$ & $\begin{array}{l}\text { Pseudomonas, Rhdococcus } \\
\text { sp. }\end{array}$ & Triazine herbicides & $\begin{array}{l}\text { Sharma, Babitaet } \\
\text { al., (2018). }\end{array}$ \\
\hline
\end{tabular}

\section{Factor affecting bioremediation}

Bioremediation is a complex procedure which is affected by several factors such as microbial population (growth until critical biomass is reached, mutation and horizontal gene transfer, enzyme induction, enrichment of the capable microbial population, production of total metabolites), environmental factors, the degradation rate of contaminants by microbes is influenced by the factors like oxygen supply, moisture, nutrient supply, $\mathrm{pH}$, temperature (Luka, Y. et al., 2018). Some of the factors such as energy source, bioavailability, biochemistry, and bioactivity and some non-scientific criteria such as regulatory factor, research and technical factors, human resource factor, economic and liability factor etc also responsible for influencing bioremediation process (Boopathy, R. 2000).

\section{Bioavailability of pollutants:}

The contaminant interacts surrounding environments to alternate its bioavailability or availability to organisms which might be capable of degrading it. The in situ microbial 
Towards Excellence: An Indexed, Refereed \& Peer Reviewed Journal of Higher Education / Ms. Priyanka Gajjar, Ms. Nidhi Gondaliya, Ms. Ankita Patel \& Ms. Hiral Shah/ Page 507-526

degradation of organic pollutants is a characteristics availability of contaminant and catabolic activity of microbes (Boopathy, R. 2000).The amount of pesticides can take up by microbes is known as bioavailability is a foremost limitation of bioremediation which is affect the process by many ways such as increased microbial conversion capacities do not lead to higher biotransformation whilst mass switch is a limiting factor. Various Physico-chemical processes such as sorption, desorption, diffusion and dissolution are process used to control bioavailability contaminant. The problem of bioavailability is overcome by the use of food grade surfactant, which increase the availability of contaminants for microbial degradation (Boopathy R., 2000).

\section{Nutrients:}

To maintain microbial growth population, oxygen and nitrogen main nutrient for microbial activity and cell growth (Khan, N. T., 2018). For cellular metabolism and proliferation at the polluted sites microbes required minerals such as potassium, nitrogen, phosphorous in the different proportion (C:P and $\mathrm{C}: \mathrm{N}$ should be 30:1 and 10:1) during degradation (Kumar, V. et al., 2018).

\begin{tabular}{llll}
\hline Elements & Percentage & Element & Percentage \\
\hline Carbon & 50 & Sodium & 1 \\
Nitrogen & 14 & Calcium & $0-5$ \\
Oxygen & 20 & Magnesium & $0-5$ \\
Hydrogen & 8 & Chloride & $0-5$ \\
Phosphorous & 3 & Iron & $0-2$ \\
Sulphur & 1 & All others & $0-3$ \\
Potassium & 1 & & \\
\hline
\end{tabular}

Adapted from Vidali, Mn. (2001).

\section{Environmental parameters:}

Microbes needs optimum environmental features like oxygen, temperature, $\mathrm{pH}$, moisture, oxygen content, nutrient content, types of soil etc. for their better growth and hence these factors also influence the quality of biodegradation (Khan, N. T., 2018).

\section{Temperature:}


Towards Excellence: An Indexed, Refereed \& Peer Reviewed Journal of Higher Education / Ms. Priyanka Gajiar, Ms. Nidhi Gondaliya, Ms. Ankita Patel \& Ms. Hiral Shah/ Page 507-526

Bioremediation of pollutants carried out by enzymatic activity of microorganisms and it is influenced by fluctuation of temperature rate, for example mesophilic bacteria required optimum growth temperature $25^{\circ} \mathrm{C}$ while thermophilic bacteria grow best above $65^{\circ} \mathrm{C}$. enzymatic reaction of microbial cell is doubled via ranges upward push in temperature and there is highest temperature restriction that microbes can face up to (Khan, N. T. 2018).

pH:

Microbial growth and enzymatic activity are readily affected by the $\mathrm{pH}$ which is vital step in bioremediation. Most microbial species can survive at optimum $\mathrm{pH}$ and hence for the degradation of compound optimum $\mathrm{pH}$ is required and it is varying with the nature of compound and microbes involved in it (Odukkathil G and Vasudevan N, 2013). Many heterotropic bacteria have a optimum $\mathrm{pH}$ range for their growth is 5.5 to 8 and the $\mathrm{pH}$ range within which bioremediation efficiently proceed is also same, and it is influenced by a complex relationship between organisms, contaminant chemistry, and physical and chemical properties of the environment, and hence this fluctuation will influence dissolution or precipitation of soil metals and may increase the mobility of hazardous material (Kah, Melanie, et al., 2007).

\section{Moisture content:}

Water is primary requirement of not only microorganisms but also required for the transport of nutrients, metabolic products and to determine the bioavailability of microorganisms and hence if water content if extremely high, there is difficulty in penetration of oxygen into soil which is objectionable effect on microbial growth (Odukkathil, Greeshma, and Namasivayam Vasudevan, 2013).

\section{Biodegradability of contaminant:}

Microbial metabolism of such organic chemical substances present in contaminated soil are common in nature is difficult and hence many methods involved for the biodegradation of organic pollutants. Many enzymatic reactions responsible for the biodegradation and the enzymes involved in this mechanism such as oxidoreductase, hydrolase, lyases, transferase, isomerase and ligases. Aromatic hydrocarbons are degraded by the oxygenase enzyme, toluene dioxygenase is also able to degraded more than 100 compounds such as TCE, nitrobenzene, chlorobenzene, esterase, depolymerase, decarboxylase etc enzymes are used for the biodegradation (Hatzikioseyian, Artin, 2010). 
Towards Excellence: An Indexed, Refereed \& Peer Reviewed Journal of Higher Education / Ms. Priyanka Gajiar, Ms. Nidhi Gondaliya, Ms. Ankita Patel \& Ms. Hiral Shah/ Page 507-526

\section{Advantage and Disadvantage of Bioremediation}

\begin{tabular}{|c|c|c|}
\hline Sr. No. & Advantage & Disadvantage \\
\hline 1 & $\begin{array}{l}\text { It is a natural process used for } \\
\text { degradation of waste from } \\
\text { contaminated water or soil. }\end{array}$ & $\begin{array}{l}\text { Entire hazardous compounds are not able to } \\
\text { bioremediate completely, it is limitation of } \\
\text { bioremediation. }\end{array}$ \\
\hline 2 & $\begin{array}{l}\text { It is beneficial process for the } \\
\text { complete destruction of } \\
\text { contaminants or some contaminants } \\
\text { are toxic which cannot completely } \\
\text { degrade are transformed into } \\
\text { harmless compound. }\end{array}$ & $\begin{array}{l}\text { There are some apprehensions that the } \\
\text { products of biodegradation may be more } \\
\text { persistent or lethal than the parent } \\
\text { composites. }\end{array}$ \\
\hline 4 & $\begin{array}{l}\text { Entire degradation of pollutant is } \\
\text { possible in place of transferring } \\
\text { contaminant from on } \\
\text { environmental medium to other i.e } \\
\text { from land to water to air. }\end{array}$ & $\begin{array}{l}\text { Biological approaches are frequently } \\
\text { notably unique. Important elements required } \\
\text { for fulfilment of process such as presence of } \\
\text { metabolically capable microbial } \\
\text { populations, appropriate environmental } \\
\text { boom situations, and appropriate ranges of } \\
\text { nutrients and contaminants. }\end{array}$ \\
\hline 5 & $\begin{array}{l}\text { It is regularly carried out on site } \\
\text { without influencing normal } \\
\text { activities. }\end{array}$ & $\begin{array}{l}\text { It is tough to extrapolate from bench and } \\
\text { pilot scale studies to full scale field } \\
\text { operation. }\end{array}$ \\
\hline 6 & $\begin{array}{l}\text { It is cost effective, less efforts } \\
\text { required for foremost disruption, } \\
\text { also eliminate chances of future } \\
\text { liability, most sustainable, and an } \\
\text { eco-friendly method used for clean- } \\
\text { up of hazardous waste. }\end{array}$ & $\begin{array}{l}\text { Research is required to expand and engineer } \\
\text { bioremediation process which might be } \\
\text { appropriate for on site with complex } \\
\text { mixture of pollutants which might be not } \\
\text { calmly dispersed in the surroundings. } \\
\text { Contaminants may be present in the form of } \\
\text { solid, liquid or gases. }\end{array}$ \\
\hline 7 & $\begin{array}{l}\text { It is relatively } \\
\text { implementation. }\end{array}$ & $\begin{array}{l}\text { It frequently takes longer than other } \\
\text { treatment options, such as excavation and } \\
\text { elimination of soil or incineration. } \\
\text { Evaluation of bioremediation is tough, } \\
\text { being often highly definite and there is no } \\
\text { satisfactory endpoints for this treatment. }\end{array}$ \\
\hline
\end{tabular}

(Gavrilescu, Maria., 2005, Kensa, V. Mary. 2011, Endeshaw, A., et al., 2017).

\section{Future perspective of Bioremediation}

Bioremediation is a natural and diverse process alternative to many conventional physicochemical methods and have proven to effective in restoring polluted sites with different contaminants (Das, Manab, et al., 2013). Potent microbial population play key role in bioremediation process and hence their diversity, abundance and community structure in contaminated environment deliver insight into the fate of any bioremediation process provided other environmental factors, which can delay microbial activities are maintained at the optimal range. To know the bioremediation by microbial population there are many 
molecular techniquessuch as metagenomics, proteomics, genomics, and transcriptomics used to understand the microbial identification, its functions, metabolic and catabolic pathways, and by this way overcoming the problem associated with culture dependent methods (Azubuike, Christopher Chibueze, et al., 2016).Its significant to highlight that numerous field experiments have no longer been regulated properly, designed efficaciously, or analysed nicely which has brought about ambiguity. Hence forthcoming field studies should permit severe endeavours by several approaches and provide high quality data. Many indigenous microbial flora involved in this process and to understand the mechanism involved to bioremediate organic pollutant, disintegrate pathways, which enzymes have ability for degradation should researched. The forthcoming exploration must also attention at the enzyme structure and the vicinity of gene implied during the disintegration of the organic contaminants. To enhance the capabilities of microbes for degradation another approaches such as biomolecular engineering required (Kumar, Vineet. et al., 2018). 


\section{References}

1. AHMAD, MASOOD, and IRSHAD AHMAD. "Bioremediation of Pesticides." Biotechnology book (2014).

2. Aimeur, Nadjet, et al. "Bioremediation of pesticide (mancozeb) by two Aspergillus species isolated from surface water contaminated by pesticides." J Chem Pharm Sci 9.4 (2016): 2668-2670.

3. Akashe, Megha M., Uday V. Pawade, and Ashwin V. Nikam. "www. ijrap. net."

4. Aktar, Wasim, Dwaipayan Sengupta, and Ashim Chowdhury. "Impact of pesticides use in agriculture: their benefits and hazards." Interdisciplinary toxicology 2.1 (2009): 1-12.

5. Aulakh, Milkha S., and Gurjant S. Sidhu. "Soil degradation in India: Causes, major threats, and management options." MARCO symposium. 2015.

6. Azubuike, Christopher Chibueze, Chioma Blaise Chikere, and Gideon ChijiokeOkpokwasili. "Bioremediation techniques-classification based on site of application: principles, advantages, limitations and prospects." World Journal of Microbiology and Biotechnology 32.11 (2016): 180.

7. Boopathy, R. "Factors limiting bioremediation technologies." Bioresource technology 74.1 (2000): 63-67.

8. Central Food Technological Research Institute (2003). Report ofanalysis of pesticide residues in soft drink samples, Mysore, India.

9. Das, Manab, et al. "A study of abandoned ash ponds reclaimed through green cover development." International journal of phytoremediation 15.4 (2013): 320-329.

10. Endeshaw, A., et al. "Application of microorganisms in bioremediation-review J." Environ. Microb 1.1 (2017): 2-9.

11. Esposito, Elisa, Sara M. Paulillo, and Gilson P. Manfio. "Biodegradation of the herbicide diuron in soil by indigenous actinomycetes." Chemosphere 37.3 (1998): 541-548.

12. Feng, Shuyue, et al. "Degradation Characteristics of Soil-Quality-Related Physical and Chemical Properties Affected by Collapsing Gully: The Case of Subtropical Hilly Region, China." Sustainability 11.12 (2019): 3369.

13. Garcia, F. Prieto, et al. "Pesticides: classification, uses and toxicity. Measures of exposure and genotoxic risks." J. Res. Environ. Sci. Toxicol 1.11 (2012): 279-293.

14. Gavrilescu, Maria. "Fate of pesticides in the environment and its bioremediation." Engineeringin life sciences 5.6 (2005): 497-526. 
15. Geetha, M., and M. H. Fulekar. "Bioremediation of pesticides in surface soil treatment unit using microbial consortia." African Journal of Environmental Science and Technology 2.2 (2008): 036-045.

16. Hatzikioseyian, Artin. "Principles of bioremediation processes." Trends in Bioremediation and Phytoremediation. India: Research Signpost (2010).

17. Kah, Melanie, Sabine Beulke, and Colin D. Brown. "Factors influencing degradation of pesticides in soil." Journal of agricultural and food chemistry 55.11 (2007): 4487-4492.

18. Karigar, Chandrakant S., and Shwetha S. Rao. "Role of microbial enzymes in the bioremediation of pollutants: a review." Enzyme research 2011 (2011).

19. Kensa, V. Mary. "Bioremediation-an overview." I Control Pollution 27.2 (2011): 161168.

20. Khan, N. T. "Bioremediation-An Effective Cleanup Technology." Environ Sci Ind J 14.1 (2018): 170.

21. Kulkarni, Amritha G., and B. B. Kaliwal. "Bioremediation of methomyl by soil isolatePseudomonas aeruginosa." J Environ Sci, Toxicol Food Technol 8.12 (2014): 1-10.

22. Kumar, Vineet, S. K. Shahi, and Simranjeet Singh. "Bioremediation: an eco-sustainable approach for restoration of contaminated sites." Microbial bioprospecting for sustainable development. Springer, Singapore, 2018. 115-136.

23. Lal, Rup, et al. "Pseudomonas sp. to Sphingobium indicum: a journey of microbial degradation and bioremediation of hexachlorocyclohexane." Indian Journal of Microbiology 48.1 (2008): 3-18.

24. Luka, Y., B. K. Highina, and A. Zubairu. "Bioremediation: A solution to environmental pollution-a review." Am J Eng Res 7.2 (2018): 101-109.

25. Mieldazys, A., et al. "Agriculture-Use of pesticides/plant protection products." EUOSHA. Available in September (2015).

26. Mustapha, Mohammed Umar, et al. "An Overview on Biodegradation of Carbamate Pesticides by Soil Bacteria." Pertanika Journal of Science \& Technology 27.2 (2019).

27. Nagata, Yuji, Yoshiyuki Ohtsubo, and Masataka Tsuda. "Properties and biotechnological applications of natural and engineered haloalkane dehalogenases." Applied microbiology and biotechnology 99.23 (2015): 9865-9881.

28. Odukkathil, Greeshma, and Namasivayam Vasudevan. "Residues of endosulfan in surface and subsurface agricultural soil and its bioremediation." Journal of environmental management 165 (2016): 72-80. 
Towards Excellence: An Indexed, Refereed \& Peer Reviewed Journal of Higher Education / Ms. Priyanka Gajiar, Ms. Nidhi Gondaliya, Ms. Ankita Patel \& Ms. Hiral Shah/ Page 507-526

29. Pandey, Raj Kumar, Salil Tewari, and Lakshmi Tewari. "Lignolytic mushroom Lenzites elegans WDP2: Laccase production, characterization, and bioremediation of synthetic dyes." Ecotoxicology and environmental safety 158 (2018): 50-58.

30. Parte, Satish G., Ashokrao D. Mohekar, and Arun S. Kharat. "Microbial degradation of pesticide: a review." African journal of microbiology research 11.24 (2017): 992-1012.

31. Pereira, Vanderley José, et al. "Physical-chemical properties of pesticides: concepts, applications, and interactions with the environment." Bioscience Journal 32.3 (2016).

32. Pradhan, A. N. U. P. A. M. A., S. K. Markande, and RAKESH KUMAR Kurre. "Evaluation of impact of pesticides on the basis of their physico-chemical properties." Journal of Industrial Pollution Control 30.2 (2014): 223-226.

33. Prashar, Pratibha, and Shachi Shah. "Impact of fertilizers and pesticides on soil microflora in agriculture." Sustainable agriculture reviews. Springer, Cham, 2016. 331361.

34. Radhika, M., and M. Kannahi. "Bioremediation of pesticide (Cypermethrin) using bacterial species in contaminated soil." Int J CurrMicrobiolAppl Sci 3 (2014): 427-435.

35. Rani, Kavita, and Geeta Dhania. "Bioremediation and biodegradation of pesticide from contaminated soil and water-a noval approach." Int J CurrMicrobiol App Sci 3.10 (2014): 23-33.

36. Salaria, Neha, Sandeep Sharma, and Sarika Sharma. "Actinomycetes: Potential and Applications."

37. Schrijver, Adinda De, and René De Mot. "Degradation of pesticides by actinomycetes." Critical reviews in microbiology 25.2 (1999): 85-119.

38. Sette, Lara D., Valéria M. De Oliveira, and Gilson P. Manfio. "Isolation and characterization of alachlor-degrading actinomycetes from soil." Antonie van Leeuwenhoek 87.2 (2005): 81-89.

39. Sharma, A. N. I. T. A., et al. "Microbial degradation of pesticides for environmental cleanup." Bioremediation ofIndustrial pollutants (2016).

40. Sharma, Babita, Arun Kumar Dangi, and Pratyoosh Shukla. "Contemporary enzyme based technologies for bioremediation: a review." Journal of environmental management 210 (2018): 10-22.

41. Singh, B. K., and R. C. Kuhad. "Biodegradation of lindane ( $\gamma$-hexachlorocyclohexane) by the white-rot fungus Trameteshirsutus." Letters in applied microbiology 28.3 (1999): 238241. 
Towards Excellence: An Indexed, Refereed \& Peer Reviewed Journal of Higher Education / Ms. Priyanka Gajiar, Ms. Nidhi Gondaliya, Ms. Ankita Patel \& Ms. Hiral Shah/ Page 507-526

42. Uqab, Baba, S. Mudasir, and R. Nazir. "Review on bioremediation of pesticides." J BioremediatBiodegrad 7.343 (2016): 2.

43. Vidali, Mn. "Bioremediation. an overview." Pure and applied chemistry 73.7 (2001): 1163-1172.

44. Wang, H., et al. "Biodegradation of atrazine by Arthrobacter sp. C3, isolated from the herbicide-contaminated corn field." International journal of environmental science and technology 13.1 (2016): 257-262.

45. Yadav, ISHWAR CHANDRA, and NINGOMBAM LINTHOINGAMBI Devi. "Pesticides classification and its impact on human and environment." Environmental Science and Engineering 6 (2017): 140-158.

46. Zacharia, James Tano. "Identity, physical and chemical properties of pesticides." Pesticides in the modern world-trends in pesticides analysis (2011): 1-18.

47. Zaidi, Almas, Parvaze Ahmad Wani, and Mohammad Saghir Khan. "Bioremediation: A natural method for the management of polluted environment." Toxicity of Heavy Metals to Legumes and Bioremediation. Springer, Vienna, 2012. 101-114.

48. Zalidis, George, et al. "Impacts of agricultural practices on soil and water quality in the Mediterranean region and proposed assessment methodology." Agriculture, Ecosystems \& Environment 88.2 (2002): 137-146.

49. Zhang, WenJun, FuBin Jiang, and JianFengOu. "Global pesticide consumption and pollution: with China as a focus." Proceedings of the International Academy of Ecology and Environmental Sciences 1.2 (2011): 125.

Websites

1. https://andrewtlex.wixsite.com/bioremediation/history

2. https://pubs.acs.org/doi/pdf/10.1021/bk-1984-0255.ch01

Priyanka Gajjar

Department of Microbiology and Biotechnology, School of Science, Gujarat University, Ahmedabad, Gujarat

\&

Nidhi Gondaliya

Department of Life science, School of sciences, Gujarat University

Ahmedabad, Gujarat

\&

Corresponding Author Ananya Institute of Science, Kalol, Gandhinagar, Gujarat Ankita Patel \& Hiral Shah

311hiral@gmail.com 